\title{
Occupational exposures and symptoms of hearing loss among traffic police wardens, Karachi Pakistan.
}

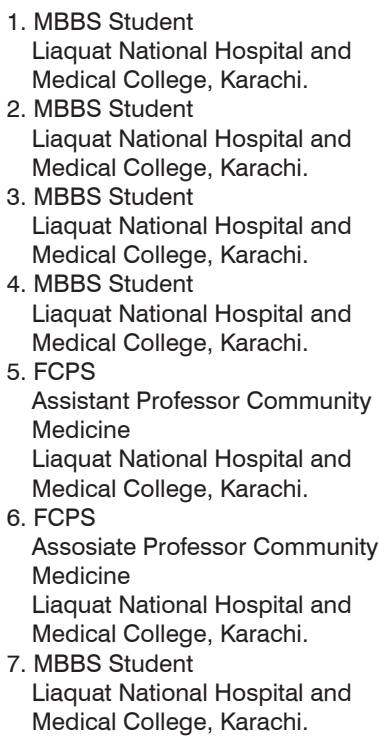

Correspondence Address:

Dr. Aneeta Khoso

Department of Community Medicine

Liaquat National Hospital and Medical College, Karachi.

aneetakhoso@gmail.com

Article received on:

11/03/2021

Accepted for publication:

26/05/2021

\section{INTRODUCTION}

Occupation is a major determinant of health. There are many countries where Work-Related Diseases (WRDs) are either underdiagnosed or are incorrectly reported. ${ }^{1}$ In their 2013 report, the International Labor Organization (ILO) declared Occupational diseases as a "hidden epidemic". According to the ILO estimates, every year occupational injury or disease claims the lives of over 2.3 million women and men, of which fatal accidents account for over 350,000 deaths, while almost 2 million deaths are attributed to fatal work-related diseases. ${ }^{3}$

Certain occupations carry a risk greater than others. Traffic police personnel are involved in an occupation that leaves them vulnerable to various exposures, that accumulate over time and have a deleterious impact on their overall health. ${ }^{4}$ Vehicular noise is one of the main contributors to hearing loss. ${ }^{5}$ Several developing countries, like Pakistan, have witnessed a surge in the use and ownership of motor vehicles, thus raising the level of noise pollution. ${ }^{6}$ Tinnitus, difficulty in hearing high-pitched sounds, or conversations in a noisy place, difficulty in understanding speech over the phone, asking others to speak more slowly and clearly or more loudly or to repeat what they said, turning up the volume of the television or radio are some of the symptoms that people with hearing loss present with. ${ }^{7}$ What we have are mere estimates available regarding frequencies of hearing loss from national statistics, which often are heterogeneous in regards to definitions, data collection methodologies, and quality, especially when it comes to developing countries. There is 
a dearth of data regarding the burden of hearing impairment associated with occupational noise among traffic police in a metropolitan city like Karachi.

This study intended to assess the frequency and associations of symptoms of hearing loss among traffic police wardens of Karachi, due to their occupational exposure.

\section{MATERIAL \& METHODS}

It was an Observational (Cross-sectional) study involving traffic police wardens as participants, selected through non-probability purposive sampling technique. The study was conducted from January to June 2019, following the approval from the Ethical Committee (0470-2019-LNHERC). of the Liaquat National Hospital and Medical College, Karachi. The WHO program "Sample Size Determination in Health Studies" was used to calculate the sample size. At 95\% confidence level and 5\% bound on the error, the sample size calculated was $181 .{ }^{8}$ Traffic police wardens available at their respective stations and having work experience of more than 2 years were included in the study. The areas included the Saddar, Stadium road, Newtown, Nazimabad, and Clifton. These areas were selected based on the accessibility of the data collectors (Medical students), considering the law and order situation of the city Karachi. They were also selected based on the survey of the city considering the easy availability of traffic police officers. The officers who did not have time to respond to the questions were contacted when they were relatively free from work. The officers who refused to be a part of the study or those who had recently been transferred to Karachi from any other city were excluded from the study. A self-administered questionnaire was developed by Public Health faculty and experts; this was done using previous research in the field. The questionnaire was developed in the English language followed by a translation in the local language, Urdu. The questionnaire was also back-translated for increasing the validity of the questions.

A relatively private and quiet place was managed at each station to fill in the questionnaire. The study objectives were briefed to the participants and they were assured regarding the confidentiality and anonymity of the information collected. They were also informed that their participation will be completely voluntary and that they would not be forced or reimbursed in any way. The participants were required to give written informed consent to participate in the study.

We used IBM SPSS Statistics version 22 for the data entry and analysis. After entering the data, it was cleaned thoroughly. We used frequencies to assess the basic socio-economic and workrelated statistics. For determining the association of tinnitus, which is the major symptom of hearing loss, we used univariable and multivariable regression analysis. A model was created regressing several variables and confounders, that explained the outcome variable. We considered a p-value less than 0.05 as significant.

\section{RESULTS}

Table-I shows the socio-demographic characteristics of the 181 traffic police wardens. Most of them were young (Mean $=29.96, S D=$ $5.98)$, with a matriculate degree (49.7\%), nonsmokers (95\%), having no co-morbidities (97.2\%), with no family history of hearing loss.

Table-Il shows the work-related characteristics of the traffic police wardens and the exposures they have experienced at work. Most of them (97.8\%) documented working in noisy places, with Saddar being the loudest area of work (mentioned by $39.2 \%)$. Almost none of the wardens (98.3\%) used any hearing protection devices during work or had undergone a hearing test $(98.9 \%)$.

Figure-1 shows the symptoms of hearing loss among the traffic police wardens. Among those who mentioned ringing sound in their ears (tinnitus), 49.2\% mentioned the buzzing being constant, while for $50.8 \%$ it was intermittent. For $27.8 \%$ the experience involved only one ear, while $72.2 \%$ mentioned hearing it in both ears (not shown in the graph).

Table-III shows the results of univariable and multivariable regression analysis of tinnitus among 
police wardens, relating the symptoms to their education, job description, and duration, whether working in a noisy area, loudest workplace ever, and exposure to sudden loud noises. Age was a confounder.

According to the results, on univariate regression analysis, we found significant associations between the symptom of tinnitus and variables like educational level, job description, and duration, history of working in a noisy area, loudest workplace ever among the traffic police wardens. After adjusting with age, we found some variations in the results. Compared to the traffic police wardens with higher education levels the wardens who had studied till primary grade or matriculation were 3.50 times more likely to experience tinnitus. Workers who had worked for more than 36 months' duration were found to be protected, compared to the workers who had worked for less than 36 months' duration (OR: $0.37 ; 95 \% \mathrm{Cl}$ : 0.16-0.86). Traffic wardens who worked in a noisy environment and those who had experienced sudden noise exposures in their lifetime were less likely to report tinnitus
(OR: $0.20 ; 95 \% \mathrm{Cl}: 0.06-0.71$ and OR: $0.23 ; 95 \%$ Cl: 0.09-0.60, respectively).

\section{DISCUSSION}

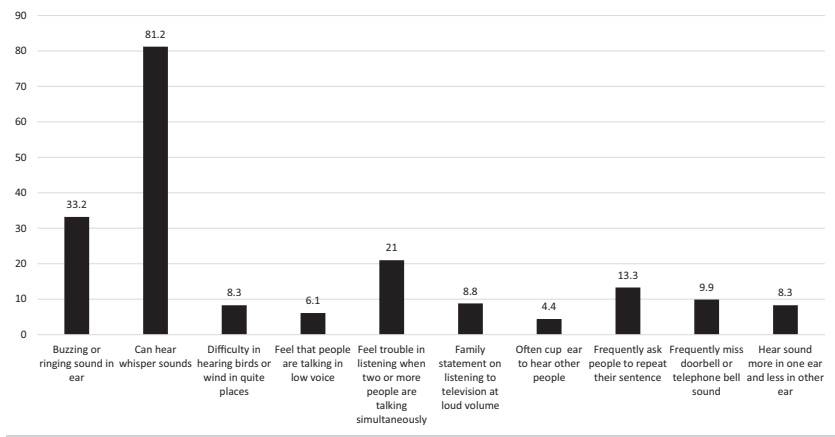

Figure-1. Symptoms of hearing loss among traffic police wardens (percentages; $n=181$ ).

This was a study group whereby a great majority of the traffic police workforce was using no hearing protective equipment, although they were working in an extremely noisy environment. They had never gone through any hearing test, as documented by them.

\begin{tabular}{|c|c|c|}
\hline Variables & Frequency & Percentages \\
\hline Age in years & Mean $=29.96$ & $\mathrm{SD}=5.98$ \\
\hline $\begin{array}{l}\text { Education level } \\
\text { Primary } \\
\text { Matriculation } \\
\text { Intermediate } \\
\text { Graduation } \\
\text { Post graduation }\end{array}$ & $\begin{array}{c}4 \\
90 \\
61 \\
25 \\
1\end{array}$ & $\begin{array}{c}2.2 \\
49.7 \\
33.7 \\
13.8 \\
0.6\end{array}$ \\
\hline Monthly household income (Rupees) & Mean $=35,229$ & $S D=11,140$ \\
\hline $\begin{array}{l}\text { Number of household members } \\
\qquad 5 \\
>5\end{array}$ & $\begin{array}{c}70 \\
111\end{array}$ & $\begin{array}{l}38.9 \\
61.1\end{array}$ \\
\hline $\begin{array}{c}\text { Co-morbidities } \\
\text { Yes } \\
\text { No }\end{array}$ & $\begin{array}{c}5 \\
176\end{array}$ & $\begin{array}{c}2.8 \\
97.2\end{array}$ \\
\hline $\begin{array}{c}\text { Smoking history } \\
\text { Yes } \\
\text { No }\end{array}$ & $\begin{array}{c}9 \\
172\end{array}$ & $\begin{array}{c}5 \\
95\end{array}$ \\
\hline $\begin{array}{l}\text { Family history of hearing loss } \\
\text { Yes } \\
\text { No }\end{array}$ & $\begin{array}{c}2 \\
179\end{array}$ & $\begin{array}{c}1.1 \\
98.9\end{array}$ \\
\hline
\end{tabular}




\begin{tabular}{|c|c|c|}
\hline Variables & Frequency & Percentages \\
\hline Duration of work as traffic police (months) & Median $=48$ & IQR $=48$ \\
\hline $\begin{array}{l}\text { Part-time work in other occupation } \\
\text { Yes } \\
\text { No }\end{array}$ & $\begin{array}{c}0 \\
181\end{array}$ & $\begin{array}{c}0 \\
100\end{array}$ \\
\hline $\begin{array}{l}\text { Regularly worked at noisy area } \\
\text { Yes } \\
\text { No }\end{array}$ & $\begin{array}{c}77 \\
4\end{array}$ & $\begin{array}{c}97.8 \\
2.2\end{array}$ \\
\hline $\begin{array}{l}\text { Currently working at noisy area } \\
\text { Yes } \\
\text { No }\end{array}$ & $\begin{array}{c}128 \\
53\end{array}$ & $\begin{array}{l}70.7 \\
29.3\end{array}$ \\
\hline $\begin{array}{l}\text { Lifetime exposure to sudden loud sound } \\
\text { Yes } \\
\text { No }\end{array}$ & $\begin{array}{c}145 \\
36\end{array}$ & $\begin{array}{l}80.1 \\
19.9\end{array}$ \\
\hline Duration of exposure to sudden loud sound & Mean $=7$ & $S D=3.14$ \\
\hline $\begin{array}{l}\text { Ever worked in a quiet place during last two years } \\
\text { Yes } \\
\text { No }\end{array}$ & $\begin{array}{c}0 \\
181\end{array}$ & $\begin{array}{c}0 \\
100\end{array}$ \\
\hline $\begin{array}{l}\text { Use of hearing protecting equipment during work } \\
\text { Yes } \\
\text { No }\end{array}$ & $\begin{array}{c}3 \\
178\end{array}$ & $\begin{array}{c}1.7 \\
98.3\end{array}$ \\
\hline $\begin{array}{l}\text { Loudest work place ever experienced } \\
\text { Saddar } \\
\text { Stadium road } \\
\text { Newtown } \\
\text { Nazimabad } \\
\text { Clifton } \\
\text { Other }\end{array}$ & $\begin{array}{l}71 \\
36 \\
19 \\
15 \\
11 \\
29\end{array}$ & $\begin{array}{c}39.2 \\
19.9 \\
10.5 \\
8.3 \\
6.1 \\
16\end{array}$ \\
\hline $\begin{array}{l}\text { Current ENT problem } \\
\text { Yes } \\
\text { No }\end{array}$ & $\begin{array}{c}12 \\
169\end{array}$ & $\begin{array}{c}6.6 \\
93.4\end{array}$ \\
\hline $\begin{array}{l}\text { Ever had hearing test } \\
\text { Yes } \\
\text { No }\end{array}$ & $\begin{array}{c}2 \\
177\end{array}$ & $\begin{array}{c}1.1 \\
98.9\end{array}$ \\
\hline
\end{tabular}

Pakistan, and for that matter, many developing countries, lack such occupational health regulations that help in creating an enabling environment for the employee. .,10 $^{10}$ These include having regular health assessments, for example pre-employment health check-ups and most important, fitting the worker to the job, which is the main aim of Ergonomics. ${ }^{11}$

The working condition in certain occupations impacts the quality of work and performance of the worker. Although, human performance in any workplace is affected by several factors, including but not limited to the nature of the job and its complexity, job context, and improper working conditions which constitute ventilation, light, humidity, dust level, noise, and air quality. However, noise is considered the hardest variable to deal with, considering its subjective phenomenon. ${ }^{12}$

In our study, the results show that there were workers who denied having ever smoked, or even having any hearing impairment. 


\begin{tabular}{|c|c|c|}
\hline & \multicolumn{2}{|c|}{ Symptoms of Tinnitus } \\
\hline & \multicolumn{2}{|c|}{ OR $(95 \% \mathrm{Cl})$} \\
\hline Variables & \multirow[b]{2}{*}{$\begin{array}{c}0.453(0.24-0.85) \text { * } \\
1.00\end{array}$} & Adjusted\$ \\
\hline $\begin{array}{l}\text { Education } \\
\text { Primary and matriculation } \\
\text { Intermediate and higher }\end{array}$ & & $\begin{array}{c}3.50(1.63-7.52)^{\star \star \star} \\
1.00\end{array}$ \\
\hline $\begin{array}{l}\text { Job description } \\
\text { Police constables } \\
\text { Others }^{@}\end{array}$ & $\begin{array}{c}0.19(0.05-0.66)^{* * *} \\
1.00\end{array}$ & $\begin{array}{c}0.22(0.03-1.48) \\
1.00\end{array}$ \\
\hline $\begin{array}{l}\text { Job duration } \\
>36 \text { months } \\
\leq 36 \text { months }\end{array}$ & $\begin{array}{c}3.14(1.64-6.02) * \star \star \\
1.00\end{array}$ & $\begin{array}{c}0.37(0.16-0.86)^{*} \\
1.00\end{array}$ \\
\hline $\begin{array}{l}\text { Working in a noisy area } \\
\text { Yes } \\
\text { No }\end{array}$ & $\begin{array}{c}0.13(0.05-0.37)^{\star \star *} \\
1.00\end{array}$ & $\begin{array}{c}0.20(0.06-0.71)^{*} \\
1.00\end{array}$ \\
\hline $\begin{array}{l}\text { Loudest work place ever } \\
\text { Saddar } \\
\text { Others }{ }^{\&}\end{array}$ & $\begin{array}{c}2.58(1.30-5.12) \star \star \\
1.00\end{array}$ & $\begin{array}{c}1.51(0.68-3.37) \\
1.00\end{array}$ \\
\hline $\begin{array}{l}\text { Lifetime exposure to sudden loud } \\
\text { noises }^{\#} \\
\text { Yes } \\
\text { No }\end{array}$ & $\begin{array}{c}1.62(0.71-3.72) \\
1.00\end{array}$ & $\begin{array}{c}0.23(0.09-0.60)^{*} \\
1.00\end{array}$ \\
\hline \multicolumn{3}{|c|}{ Table-III. Regression analysis for predictors of tinnitus among traffic police wardens. $(n=181)$} \\
\hline \multicolumn{3}{|c|}{$\begin{array}{ll}{ }^{\$} \text { Adjusted for age } & { }^{*} p<0.05 * * p<0.01 * * * p<0.001 \\
{ }^{\circledR} \text { ASI, Inspector patrolling, Head constable, Sub inspector, SHO } & \text { \& Stadium road, Newtown, Nazimabad, Clifton, Others } \\
{ }^{*} \text { bomb blast, firearms, tractor etc } & \end{array}$} \\
\hline
\end{tabular}

Although statistics show that Pakistan is one of 15 countries worldwide with a heavy burden of tobacco-related ill health. Based on the World Health Organization's 2013 standardized estimate of smoking prevalence, $31.8 \%$ of men, $5.8 \%$ of women, and $19.1 \%$ of Pakistan's adult population currently use tobacco in one form or another. ${ }^{13}$

This study employed the use of a questionnaire, instead of using audiometry as a quantitative test to screen for noise-induced hearing loss among them. Due to this reason, the symptoms of hearing loss were considered. Nevertheless, some studies have assessed hearing loss among traffic police based on questionnaires, not using audiometers.

Since this was a questionnaire-based study with no possibility of a quantitative assessment of hearing loss among the traffic police wardens, hence the results need to be generalized with caution. Ideally, audiometry is done to ascertain noise-induced hearing loss; however, given the limited resources for the conduction of the study and lack of testing space at the stations, this was not possible, as determined during pretesting of the questionnaire. On the contrary, there have been researches in the past that are questionnaire-based, assessing the hearing loss in traffic police warden. ${ }^{6}$ Results of an Indian study on self-assessment of noise-induced hearing loss among traffic police and bus drivers revealed that although they were exposed to the high intensity of noise, around $60 \%$ of them rated excellent hearing. ${ }^{6}$ Similar to our study participants, the Indian traffic police and bus drivers were not using any hearing protective equipment, although they showed signs of hearing-related problems. Results of another questionnaire-based study on Indian traffic policemen showed that $11.6 \%$ of them complained of tinnitus regularly, while $62.8 \%$ had work-related tinnitus and experienced it during working hours only. ${ }^{14}$ Around $67.4 \%$ of the traffic policemen did not use any method to reduce noise exposure. Our study showed that $33 \%$ of traffic police wardens complained of tinnitus, with around $50 \%$ complaining of it being constant. 
According to our study results, those traffic police wardens who were less educated (had primary or matriculation degrees), having worked for less than 36 months, who were working in a noisy area, and those who had exposure to sudden loud noises were less likely to report symptoms of tinnitus. The possible reason could be the "Healthy worker effect" a phenomenon that has been evident in previous studies conducted on workers in varying fields, whereby those who are fitter, are more likely to be present on the field. ${ }^{15,16}$ They did not have any hearing problems, probably since they were younger and healthier. The workers with such problems would not be working in such occupations. The workers having lower ranks were less likely to report tinnitus, compared to the seniors. Also, the workers were afraid to disclose many aspects of their health issues, since they were afraid of being documented, with a threat to their jobs. Although they were re-assured regarding the data anonymity, nevertheless, this factor was also evident.

\section{CONCLUSION}

This study highlighted that traffic police workers were exposed to loud noise regularly and they suffered from the impacts of occupational exposure. The principles of Ergonomics, whereby the job is fitted according to the worker's needs to be employed, especially in developing countries like Pakistan, having a dearth of pre-employment assessments, to ensure the safety of the worker. There is a dire need to educate these workers regarding the importance and use of personal protective equipment during work time. Further research using more quantitative assessment is recommended.

Copyright@ 26 May, 2021.

\section{REFERENCES}

1. Bilal S, Mehmood F, Fazil M, Nasim S, Qureshi M, Ashraf $M$. Assessment of occupational hazards among the traffic police of rawalpindi \& islamabad. Pak Armed Forces med j. 2019; 69(5):1024-28.

2. The prevention of occupational diseases. https://www. ilo.org/wcmsp5/groups/public/---ed_protect/---protrav/--safework/documents/publication/wcms_208226.pdf. Switzerland: ILO, 2013.
3. Global trends on occupational accidents and diseases. ttps://www.ilo.org/legacy/english/osh/en/ story_content/external_files/fs_st_1-ILO_5_en.pdf. 2015.

4. Shahid S, Majid H, Ismail K, Safdar S, Hanif A, Hassan $\mathrm{SB}$. Frequency of noise induced hearing loss among traffic wardens of Lahore. Int J Adv Biotechnol Res. 2019; 10(2):254-9.

5. Singh A, Bansal A, Goel S, Goel PK, Chhikara P, Singh NK. A rapid appraisal of traffic policemen about auditory effects of traffic noise pollution from Ambala city. Med J DY Patil Univ. 2015; 8:12-5.

6. Sanju HK, Kumar P. Self-assessment of noise-induced hearing impairment in traffic police and bus drivers: questionnaire-based study. Indian J Otol. 2016; 22:162-7.

7. Centre for Disease Control and Prevention- CDC: National Center for Environmental Health. How Do I Know if I Have Hearing Loss Caused by Loud Noise? Loud Noise Can Cause Hearing Loss 2018. Available from: https://www.cdc.gov/nceh/hearing_loss/how_ do_i_know_if_i_have_hearing_loss.html.

8. Jawed I, Musani A, Mahmood R, Wadood, Khambaty $Y$, Asim M. The effect of traffic noise on the hearing level of people on Karachi streets. J Pak Med Assoc. 2010;60(10):813-6.

9. Criteria for a recommended standard... occupational noise exposure, revised criteria, (1998).

10. Chadambuka A, Mususa F, Muteti S. Prevalence of noise induced hearing loss among employees at a mining industry in Zimbabwe. Afr Health Sci. 2013; 13(4):899-906.

11. Horie S. Prevention of musculoskeletal disorders in the workplace. Journal of Japan Medical Association. 2013;56(3):186-92.

12. Wang X, Orelaja OA, Ibrahim DS, Ogbonna SM. Evaluation of noise risk level and its consequences on technical operators of tobacco processing equipment in a cigarette producing company in Nigeria. Scientific African. 2020 Jul 1;8:e00344.

13. WHO: Tobacco control in Pakistan. World Health Organization, Geneva: 2015.

14. Tripathi S, Tiwari R. Self-reported hearing quality of traffic policemen: A questionnaire-based study. Indian J Occup Environ Med. 2006; 10(2).

15. Chénard L, Senthilselvan A, Grover VK, Kirychuk SP, Lawson JA, Hurst TS, et al. Lung function and farm size predict healthy worker effect in swine farmers. Chest. 2007; 131(1):245-54. 
16. Khoso A, Wasim S, Zainab S. Prevalence and predictors of respiratory symptoms and illnesses among farmers: A cross-sectional survey. East Mediterr Health J. 2019; 5(10):698-705.

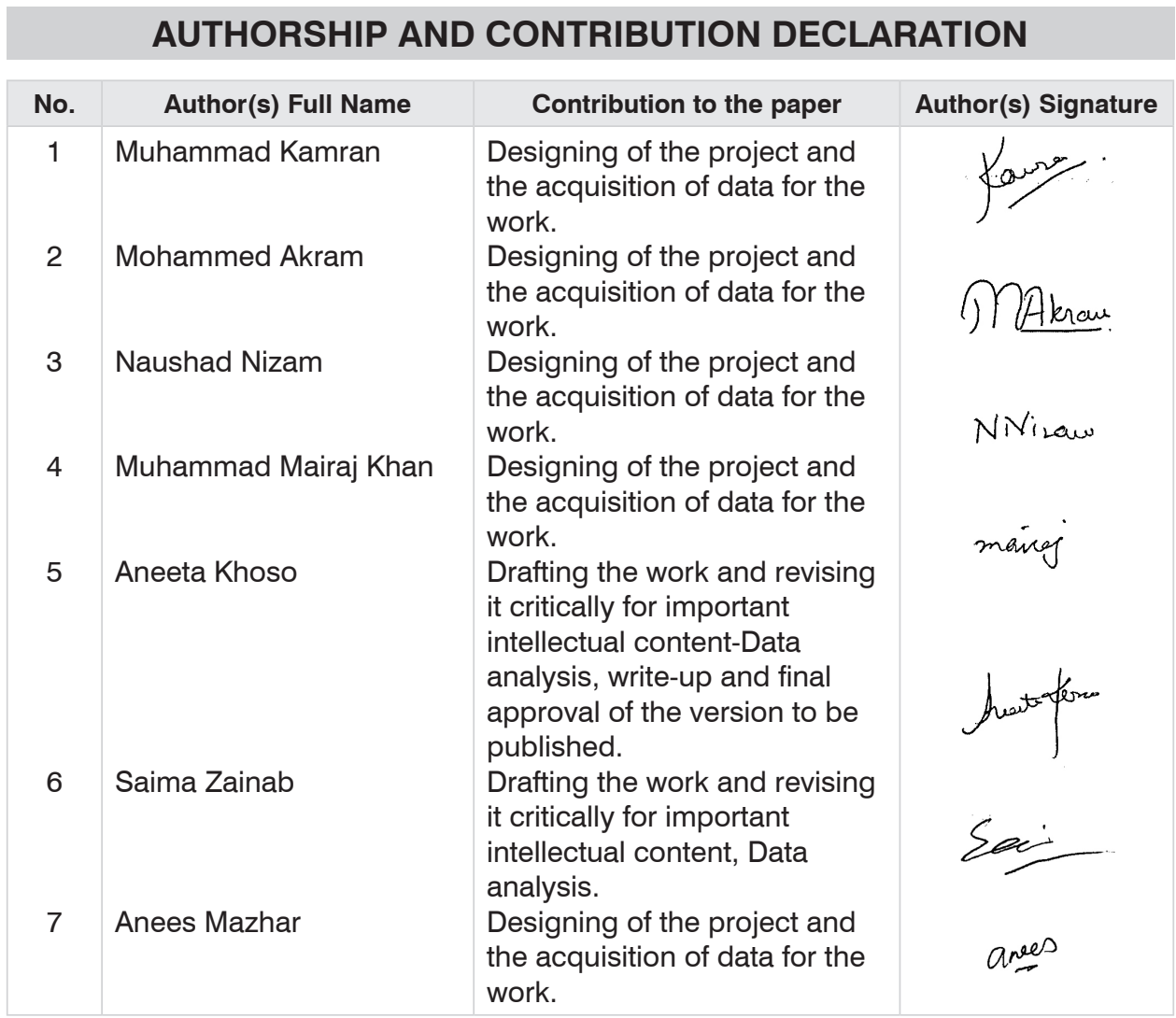

